\title{
Experimental assessment of methods of dissemination of the thermodynamic temperature at the highest temperatures
}

\author{
Mohamed Sadli ${ }^{1, a}$, Klaus Anhalt ${ }^{2}$, Frédéric Bourson ${ }^{1}$, Stephan Briaudeau ${ }^{1}$, Dolores Del Campo ${ }^{3}$, Ahmet Diril ${ }^{4}$, David Lowe ${ }^{5}$, \\ Graham Machin ${ }^{5}$, José Manuel Mantilla Amor ${ }^{3}$, Maria-Jose Martin ${ }^{3}$, Helen Mc Evoy ${ }^{5}$, Maija Ojanen ${ }^{6}$, Özlem Pehlivan ${ }^{4}$, \\ Bernard Rougié ${ }^{1}$, Saber G. R. Salim ${ }^{1,7}$ \\ ${ }^{1}$ Laboratoire commun de métrologie LNE-Cnam, 61 rue du Landy 93210 Saint-Denis, France \\ ${ }^{2}$ Physikalisch-Technische Bundesanstalt, Abbestrasse 2-12, 10587 Berlin, Germany \\ ${ }^{3}$ Centre Espanol de Metrogia, C/Alfar, 2. 28760 Tres Cantos, Madrid, Spain \\ ${ }^{4}$ TUBITAK Ulusal Metroloji Enstitusu (TUBITAK UME), Gebze Yerleşkesi, 41470 Gebze/Kocaeli, Turkey \\ ${ }^{5}$ National Physical Laboratory, Hampton Rd, Teddington, Middlesex, TW11 0LW, United-Kingdom \\ ${ }^{6}$ VTT-MIKES Tekniikantie 1, FI-02150 Espoo, Finland \\ ${ }^{7}$ National Institute of Standards NIS-Egypt; post-doctoral stay at LNE-Cnam
}

\begin{abstract}
In the frame of the European Metrology Research Programme (EMRP)-funded joint research project "Implementing the new kelvin" one work package is devoted to the assessment of two different methods of dissemination of the thermodynamic temperature. These two methods are the dissemination via high temperature fixed points (HTFP) with assigned thermodynamic temperatures and the dissemination by radiometers or radiation thermometers calibrated in terms of thermodynamic temperature. To achieve a thorough assessment of these two distinct dissemination methods two dissemination exercises were organised in the form of comparisons. In one case the circulating artefacts were off-the-shelf high-temperature fixed point cells with transition temperatures ranging from $1324{ }^{\circ} \mathrm{C}$ to $2474{ }^{\circ} \mathrm{C}$, in the other case absolutely calibrated pyrometers and filter radiometers were compared in the temperature range $1000{ }^{\circ} \mathrm{C}$ to $2500{ }^{\circ} \mathrm{C}$. This work showed that both schemes were achievable with competing advantages and drawbacks and would most probably help disseminating thermodynamic temperature in the future at the level of $1 \mathrm{~K}$ to $2 \mathrm{~K}$ uncertainty over the whole temperature range.
\end{abstract}

\begin{abstract}
Résumé. Dans le cadre du projet de recherche concertée financé par le programme européen de recherche en métrologie (EMRP) "Implementing the new kelvin", un des lots de tâches, le workpackage 2, s'attèle à l'évaluation de deux méthodes différentes de dissémination de la température thermodynamique : une méthode reposant sur l'usage de cellules points fixes à hautes températures, ayant des températures thermodynamiques affectées à leurs transitions de phase ; une seconde méthode reposant sur la dissémination à l'aide de pyromètres étalonnés en absolu ou de radiomètres à filtres traçables au radiomètre cryogénique à substitution électrique. Afin de réaliser une évaluation complète des deux méthodes, deux comparaisons ont été organisées entre laboratoires européens dans un cas en utilisant un lot de cellules à points fixes à haute température entre $1324{ }^{\circ} \mathrm{C}$ et $2474{ }^{\circ} \mathrm{C}$ et dans l'autre cas en réunissant dans un même laboratoire, le PTB, quatre instruments étalonnés en absolu et en les comparant face à un corps noir de température variable entre $1000{ }^{\circ} \mathrm{C}$ et $2500{ }^{\circ} \mathrm{C}$. Cette étude a prouvé en premier lieu que les deux méthodes peuvent être mise en œuvre avec succès et peuvent servir, en fonction des équipements disponibles en laboratoire, d'excellents moyens pour la dissémination de la température thermodynamique avec des incertitudes de l'ordre de $1 \mathrm{~K}$ à $2 \mathrm{~K}$ sur tout le domaine de température.
\end{abstract}

\section{Introduction}

The new definition of the kelvin is likely to be linked to a fundamental constant, the Boltzmann constant, in the very near future as will be the ampere, the kilogramme and the mole $[1,2]$. The new definition of the kelvin will certainly allow direct thermodynamic temperature measurement and dissemination over the whole temperature range.

Therefore, a practical realisation of the unit will need to evolve to formally include thermodynamic temperature dissemination especially in the highest range of the temperature scale: namely above the copper point $(1357.77 \mathrm{~K})$.

A joint research project (JRP), "Implementing the new kelvin, InK", funded by the European Metrology Research Programme (EMRP) was launched in September 2012 [3] to prepare the implementation of the new definition of the kelvin with two main assigned objectives in the high temperature range: assigning thermodynamic temperatures to a set of selected high-

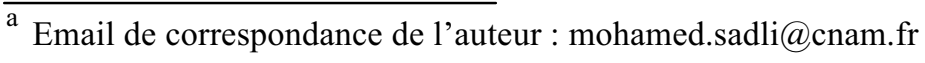


temperature fixed points and evaluating the possibilities of the dissemination of the thermodynamic temperature.

This paper will focus on the content of the work package devoted to the realisation and the dissemination of thermodynamic temperatures above $1000{ }^{\circ} \mathrm{C}$. It describes the activities performed to achieve an assessment of the possibilities of dissemination using either high-temperature fixed points or radiometers/pyrometers.

\section{2 "Implementing the new kelvin" JRP project}

The InK project [3, 4] contains four technical work packages with the following objectives/work packages, including activities already planned in a concerted international research project [5]:

- WP1: assign thermodynamic temperatures to a selected batch of high-temperature fixed points,

- WP2: assess and compare two dissemination routes for thermodynamic temperature at high temperatures,

- WP3: determine ultra-low uncertainty values for T $\mathrm{T}_{90}$ in the low temperature range,

- WP4: improve primary thermometry at low temperatures below $1 \mathrm{~K}$.

The expected outputs of this project will certainly be of importance to the international temperature community, especially as many national metrology institutes outside Europe are contributing actively to the project.

One of the main outputs will be bringing the findings of the project to be taken into account in the Mise-enPratique of the kelvin (MeP-K) [6].

In the high temperature range [7], the objective of the Mise-en-Pratique of the new definition of the kelvin, currently under preparation, is to define and explain the different ways of realising the unit and disseminating it. It will most likely include three possibilities:

- according to the international temperature scale of 1990 (ITS-90), which is the present situation,

- thermodynamic temperature through hightemperature fixed points (HTFPs) of assigned temperatures (relative absolute radiation thermometry),

- direct thermodynamic temperature.

To check whether it is more efficient to realise and disseminate thermodynamic temperature by a sourcebased or a detector-based scheme, a cooperative research work was included in the JRP InK in the second work package devoted to the dissemination of high temperatures between $1000{ }^{\circ} \mathrm{C}$ and $2500{ }^{\circ} \mathrm{C}$.

\section{Description of the work package "realisation and dissemination of thermodynamic temperatures at high temperature"}

This workpackage, led by LNE-Cnam, involves five other partners: CEM (Spain), MIKES (Finland), NPL (United-Kingdom), PTB (Germany) and TUBITAKUME (Turkey).

Two different practical thermodynamic temperature dissemination schemes for temperatures higher than $1000{ }^{\circ} \mathrm{C}$ were evaluated in this work package. Both schemes have been proposed in the Mise-en-Pratique of the kelvin: either by absolute primary thermometry, directly traceable to the electrical-substitution cryogenic radiometer, or via HTFPs of known temperatures using therefore a relative primary method.

\subsection{Dissemination using HTFPs}

Realisation and dissemination of thermodynamic temperatures using HTFPs is the subject of the first task of this workpackage. This work is performed with ITS-90 temperatures assigned to the HTFPs because definitive thermodynamic temperatures will only be available at the end of the project. This task will however help assessing the methods required for dissemination when thermodynamic temperatures become available for the HTFPs.

To achieve this dissemination exercise, NPL and LNECnam supplied two sets of HTFP cells at the Co-C, Pt-C, $\mathrm{Ru}-\mathrm{C}$ and $\mathrm{Re}-\mathrm{C}$ high-temperature fixed points. The cells were either off-the-shelf, used cells or have been constructed for this particular project.

Before the start of the circulation of the cells, the circulating batch was compared to the reference batch. This initial comparison was intended to make a link between the cells and to be able to replace a cell in case of breakage without completely losing information between the cells. This initial comparison was performed by LNE-Cnam.

Table 1. Identification of the cells participating to InK/WP2. Cells 7CO1, 7CO2, 7CO4, 5PT2, 6PT2, 4RE1 and 4RE2 were supplied by LNE-Cnam. Cells INKRU1, INKRU and PT2006-2 were supplied by NPL. Cells 7CO1 and PT2006-2 broke during the circulation process and were replaced by new cells (7CO6 and 6PT2 respectively).

\begin{tabular}{|c|c|c|}
\hline HTFP & REF WP2 & CIRC WP2 \\
\hline $\mathrm{Co}-\mathrm{C}$ & $7 \mathrm{CO} 2$ & $7 \mathrm{CO} 1$ then 7CO6 \\
\hline
\end{tabular}




\begin{tabular}{|c|c|c|}
\hline Pt-C & 5PT2 & PT2006-2 then 6PT2 \\
\hline Ru-C & INKRU & INKRU1 \\
\hline Re-C & 4RE2 & 4RE1 \\
\hline
\end{tabular}

Table 1 summarises the cells used in the circulating lot and in the reference lot. Two cells broke during this dissemination trial showing that the early designs of cells is not suitable (the case of Pt-C cell from NPL based on the $\mathrm{C} / \mathrm{C}$ sheet design) and that the $\mathrm{Co}-\mathrm{C}$ point is a difficult point for which robustness remains an issue even with the hybrid design (consisting of $\mathrm{C} / \mathrm{C}$ sheets and a graphite sleeve).

New cells were constructed by LNE-Cnam and compared to the reference batch of cells before being put back to circulation.

A comparison was performed at the end of the dissemination trial and allowed the determination of the drift of the cells. Table 2 summarises the level of this drift for each of the cells. Of course, the two broken cells could not be assessed for drift.

Table 2. Drift of the circulating cells during the dissemination trial (over a period of more than one year). Uncertainties $(\mathrm{k}=2)$ are given between brackets.

\begin{tabular}{|c|c|}
\hline Cell & Drift (unc k=2) $\mathbf{~ K}$ \\
\hline 7 CO6 & $-25(22)$ \\
\hline 7 CO1 & Unknown \\
\hline 6PT2 & $-41(18)$ \\
\hline PT2006-2 & Unknown \\
\hline INKRU1 & $27(150)$ \\
\hline 4RE1 & $28(54)$ \\
\hline
\end{tabular}

The drift can in all cases be considered as negligible in comparison with the uncertainties of temperature determination. Earlier studies have already shown that the stability of HTFPs on the long term is ensured in case of the hybrid cell design $[8,9]$ and this study shows clearly that, past the robustness issues with early designs, HTFP cells can be considered as reliable and efficient artefacts for comparisons.

Each participant to this task (CEM, PTB, NPL, UME, LNE-Cnam) reported the assigned ITS-90 temperature of the melting transition realised with the circulating HTFP cells in their facilities.
The uncertainties reported by the participants were mainly related to the ITS-90 scale and to the repeatability of the realisation of the melt.

The main sources of discrepancy of the results, besides the scale realisation, are likely to be related to the socalled furnace effect which would result in differences in the melting temperatures, as determined at the point of inflection of the melting plateau, with changing furnace conditions. This effect, due to the temperature distribution as well as to the thermal inertia of the furnace, is still under study at the international level and is likely to represent the major source of uncertainty in the use of HTFPs. Early studies have shown that it can induce uncertainties at the level of $0.1 \mathrm{~K}$ at the Re-C point [10].

At this stage, the uncertainties and temperature differences between the participating NMIs are in preparation and the results will be published elsewhere [11].

\subsection{Dissemination using absolutely calibrated filter radiometers or pyrometers}

The second dissemination scheme is performed using radiation thermometers, calibrated in terms of thermodynamic temperature, using different methods at different NMIs.

Different methods were applied by the participants (PTB, CEM, MIKES and LNE-Cnam) to calibrate a transportable radiation thermometer or a filter radiometer.

PTB has calibrated an LP3 pyrometer in terms of thermodynamic temperature by comparison to a filter radiometer through a large area high-temperature blackbody. This method is well established but it requires good temperature uniformity across the furnace opening to achieve a low uncertainty.

MIKES has used a filter radiometer (FR800) which consists of a single $\mathrm{Si}$ photodiode, an interference filter with nominal central wavelength of $800 \mathrm{~nm}$, and a 4-mm precision aperture. The relative and absolute responsivity of the diode and filter were measured with a reference spectrometer of Aalto University [12], by comparing the output of the detector with a trap detector traceable to the cryogenic radiometer of SP, Sweden. This filter radiometer has shown a large drift between the calibrations performed before and after the comparison which resulted in large uncertainties at the level of $0.4 \%$.

CEM has calibrated an LP4 radiation thermometer using their HTFP cells of $\mathrm{Cu}, \mathrm{Co}-\mathrm{C}$, Pt-C and $\mathrm{Re}-\mathrm{C}$ as references for thermodynamic temperatures. The thermodynamic temperatures assigned to these HTFPs 
were the ones assigned to these HTFPs in the first work package of the InK project [13]. A Sakuma-Hattori fit was determined to derive the relation between the photocurrent delivered by the radiation thermometer and the thermodynamic temperature over the whole range $\left(1000{ }^{\circ} \mathrm{C}\right.$ to $\left.2500^{\circ} \mathrm{C}\right)$.

Table 3. Thermodynamic temperatures of LNE-Cnam cells as determined by LNE-Cnam in WP1 of InK. These cells were used to calibrate an LP3 radiation thermometer $(850 \mathrm{~nm})$ in thermodynamic temperature using a Sakuma-Hattori fit.

\begin{tabular}{|c|c|c|}
\hline Cell & $\begin{array}{c}\text { Thermodynamic } \\
\text { temperature, } \mathbf{K}\end{array}$ & Uncertainty (k=1), K \\
\hline CuM1 & 1357.859 & 0.067 \\
\hline 7Co4 & 1597.392 & 0.095 \\
\hline 5Pt2 & 2011.410 & 0.148 \\
\hline 4Re2 & 2747.884 & 0.277 \\
\hline
\end{tabular}

LNE-Cnam applied a similar scheme as CEM except that the HTFP cells used were directly measured in terms of thermodynamic temperature using the LNE-Cnam method put in application in the WP1 of InK. The cells used for the calibration of LNE-Cnam LP3 radiation thermometer had the local assigned thermodynamic temperatures as given in table 3. A Sakuma-Hattori fit was determined using these four temperatures to have a relation between photocurrent and thermodynamic temperature.

Table 4 summarises the instruments which participated to this dissemination trial. The four instruments were gathered at PTB and put, alternatively, in front of a highemissivity high-temperature furnace, the VNIIOFI-made HTBB 3200PG. The furnace temperatures were varied in steps of $200{ }^{\circ} \mathrm{C}$ between $1000{ }^{\circ} \mathrm{C}$ and $2500{ }^{\circ} \mathrm{C}$.

At this stage, the uncertainties and temperature differences between the participating instruments are under study and the results will be published elsewhere [11].

Table 4. Instruments calibrated in terms of thermodynamic temperature at the participants laboratories and compared at PTB

\begin{tabular}{|l|l|}
\hline \multicolumn{1}{|c|}{ CEM } & \multicolumn{1}{|c|}{ PTB } \\
\hline $\begin{array}{l}\text { Radiation thermometer } \\
\text { LP4 }(650 \mathrm{~nm})\end{array}$ & $\begin{array}{l}\text { Radiation thermometer } \\
\text { LP3 }(658 \mathrm{~nm})\end{array}$ \\
\hline $\begin{array}{l}\text { Calibrated against } \\
\text { high-temperature fixed } \\
\text { points Cu, Co-C, Pt-C, Re- } \\
\text { C + Sakuma-Hattori fit }\end{array}$ & $\begin{array}{l}\text { Calibrated with respect to } \\
\text { thermodynamic } \\
\text { temperatures against filter } \\
\text { radiometer via HTBB } \\
\text { furnace }\end{array}$ \\
\hline
\end{tabular}

\begin{tabular}{|c|c|}
\hline LNE-Cnam & MIKES \\
\hline $\begin{array}{l}\text { Radiation thermometer } \\
\text { LP3 }(850 \mathrm{~nm})\end{array}$ & Filter radiometer $(800 \mathrm{~nm})$ \\
\hline $\begin{array}{l}\text { Calibrated against } 4 \text { HTFP } \\
\text { with T values assigned at } \\
\text { LNE-Cnam (WP1) + } \\
\text { Sakuma-Hattori fit }\end{array}$ & $\begin{array}{l}\text { Absolute spectral } \\
\text { responsivity }\end{array}$ \\
\hline
\end{tabular}

\section{Preliminary results and discussion}

The first findings of this study have shown that both schemes can be applied successfully, regardless to the achieved uncertainties.

HTFP cells have been circulated among five partners over a period of more than one year and have shown that they can be considered as suitable means to probe and compare the capabilities between different realisations of the scale or of thermodynamic temperatures as the WP1 of InK has already proved [13].

Using the HTFP dissemination scheme will however require the thorough assessment of the uncertainties in the realisation of the HTFPs in high-temperature furnaces. It is already admitted that different furnace inertia can result in quite large differences in melting temperatures determined at the point of inflection of the melting plateau. Moreover, the positioning of the cells in a furnace should take into account the temperature distribution. It is most likely that the highest melting temperatures would be obtained in the position corresponding to the smallest temperature gradients along the cells as reported in [10].

An additional source of uncertainty will originate from the determination of the Sakuma-Hattori fit coefficients when a radiation thermometer is calibrated in thermodynamic temperature using these dissemination artefacts. This kind of fit should be restricted to narrowband radiation thermometers $(10-20 \mathrm{~nm}$ maximum) to ensure small residuals of the fit.

Concerning the dissemination with absolutely calibrated radiation thermometers and filter radiometers, it should be noticed that the stability of the instruments was considered as satisfactory (i.e. less than about $0.5 \mathrm{~K}$ ), except for the filter radiometer of MIKES which has shown temperature equivalent drifts of $0.4 \mathrm{~K}$ to $1.8 \mathrm{~K}$ over the range $1000{ }^{\circ} \mathrm{C}-2500{ }^{\circ} \mathrm{C}$. The stability and fragility of the instruments is probably the main drawback of this method. The method requires also a uniform and high-emissivity furnace for the transfer to a 
radiation thermometer in case of use of a filter radiometer.

To summarise, the advantage of the HTFP dissemination scheme is the stability of the HTFPs which are thought to be much more achievable than the stability of radiation thermometers or filter radiometers. On the other hand, using radiation thermometers or filter radiometers as thermodynamic temperature dissemination means does not require high-temperature fixed points and specially adapted furnaces, which could be an advantage for some NMIs.

\section{Conclusion}

Two dissemination exercises were run in the frame of a European joint research project with high-temperature fixed points and, for the first time, absolutely-calibrated radiation thermometers and a filter radiometer.

These two trials have allowed the consortium to identify the main difficulties and the largest sources of uncertainty. The overall objective of assessing the possibilities offered by each of these dissemination schemes has been reached.

While the realisation and dissemination of thermodynamic temperatures based on HTFPs will need to account for the effects of the thermal conditions of implementation of the HTFP cells in different kinds of high-temperature furnaces, dissemination using radiation thermometers can be affected by the lack of stability of travelling radiation thermometers.

The final results of this study are still under consideration and should be agreed and published in the very near future. We can already state that thermodynamic temperatures at the highest temperatures can be disseminated with acceptable uncertainties of a few kelvins in both cases.

\section{References}

1. http://www.bipm.org/utils/en/pdf/24_CGPM Resolu tion 1.pdf (Resolution 1 of the CGPM (2011): On the possible future revision of the International System of Units, the SI)

2. http://www.bipm.org/utils/common/pdf/si brochure draft ch2.pdf (Section 2.3.5)

3. Machin, G., Engert, J., Gavioso, R.M., Sadli, M. \& Woolliams, E.R. "The Euramet Metrology Research Programme Project Implementing the New Kelvin (InK)". International Journal of Thermophysics 35, 405-416 (2014).

4. http://projects.npl.co.uk/ink/
5. Machin, G., Bloembergen, P., Hartmann, J., Sadli, M. \& Yamada, Y. "A concerted international project to establish high-temperature fixed points for primary thermometry. International Journal of Thermophysics 28, 1976-1982 (2007).

6. D.C. Ripple, R. Davis, B. Fellmuth, J. Fischer, G. Machin, T. Quinn, P. Steur, O. Tamura, D.R. White, Int. J. Thermophys., 31, 1795 (2010).

7. Machin, G., Bloembergen, P., Anhalt, K., Hartmann, J., Sadli, M., et al. "Practical Implementation of the Mise en Pratique for the Definition of the Kelvin Above the Silver Point". International Journal of Thermophysics 31, 1779-1788 (2010).

8. Sadli, M., Bloembergen, P., Khlevnoy,B., Wang, T., Yamada, Y., et al. "An International Study of the Long-Term Stability of Metal-Carbon Eutectic Cells" International Journal of Thermophysics 32, 1786-1799 (2011).

9. Sadli, M., Yamada, Y., Wang, T., Yoon, H.W., Bloembergen, P., et al. "Stability and robustness tests on Co-C, Pt-C and Re-C cells: the first results" Acta Metrologica Sinica 29, 59-64 (2008).

10. Bourson, F., Briaudeau, S., Rougié, B. \& Sadli, M. "Determination of the furnace effect of two hightemperature furnaces on metal-carbon eutectic points". AIP Conference Proceedings 1552, 380-385 (2013).

11. Sadli M. et al "Realisation and dissemination of thermodynamic temperatures above the silver point", to be published in Phil. Trans of Royal Society A (2015).

12. Manoochehri and E Ikonen: High-accuracy spectrometer for measurement of regular spectral transmittance, Appl. Opt. 34, 3686-3692 (1995).

13. Woolliams E.W.R et al. "Thermodynamic temperature assignment to the point of inflection of the melting curve of high temperature fixed points" submitted to Phil. Trans. R. Soc. A (2015). 